\title{
Nesting biology and potential distribution of an oil- collecting Centridine Bee from South America
}

\author{
Danny Velez ${ }^{1}$, Felipe VIVAllo ${ }^{2}$, Daniel Paiva Silva ${ }^{3}$ \\ ${ }^{1}$ Grupo de Insectos de Colombia, Universidad Nacional de Colombia, Bogotá, Colombia \\ ${ }^{2}$ HYMN Laboratório de Hymenoptera, Departamento de Entomologia, Museu Nacional, Universidade Federal do Rio de \\ Janeiro. Quinta da Boa Vista, São Cristóvão, Rio de Janeiro, RJ 20940-040, Brazil \\ ${ }^{3}$ Instituto Federal Goiano, Departamento de Biologia, Urutaí, GO 75790-000, Brazil
}

Received 16 February 2016 - Revised 18 June 2016 - Accepted 13 July 2016

\begin{abstract}
Despite their relevance for the maintenance of terrestrial ecosystems, important aspects such as the biology and distribution range remain unknown for most species of bees that occur in the Neotropical region. This makes the monitoring of pollinators and the establishment of conservation policies difficult. In this paper, we provide information on the nesting biology and natural enemies of Centris merrillae. Additionally, we provide a potential distribution model based on previously unknown occurrence records that increase the distribution range of this species through northern South America and the Caribbean. The production of such biological and biogeographic information is important to support future field surveys.
\end{abstract}

\section{Centridini / Centris merrillae / distribution range / Neotropical region / solitary bee}

\section{INTRODUCTION}

The great fame of the honeybee Apis mellifera Linnaeus and its complex and highly hierarchical system of life creates an image of bees as purely eusocial organisms. However, the reality is far from this, since less than $6 \%$ of the approximately 20,000 species of bees described worldwide exhibit social behavior (Michener 2007). The vast number of solitary species is reflected also in their diverse morphology, behavior, biology, and distribution patterns, exhibiting a wide variety of relationships with other organisms, mainly with their plant hosts, performing crucial roles in pollination processes for both natural ecosystems and agro-ecosystems (Michener 2007).

Electronic supplementary material The online version of this article (doi:10.1007/s13592-016-0463-5) contains supplementary material, which is available to authorized users.

Corresponding author: D. Velez, dannyvelezv@gmail.com

Handling Editor: Klaus Hartfelder
One of the most specious genera of the solitary bees of the New World is Centris Fabricius, with more than 230 valid species (Rasmussen and Vivallo 2014). In the Neotropics, the species of this group have an important role in ecological networks, especially in their relationships with several oil-offering plant species, mainly of the families Malpighiaceae, Krameriaceae, and Plantaginaceae (Gaglianone et al. 2011; Mello et al. 2013). Despite their relevance, the bionomy of most of the species of this genus remains unknown. For instance, the subgenus Centris (Hemisiella) Moure contains several poorly known species described mainly from South America and the Caribbean, such as C. merrillae Cockerell. Exemplars of this species are scarce in bio-collections (e.g., in Colombia, Brazil, and Trinidad and Tobago), and its biology remains largely unknown, with all information inferred from the patterns found in other species of the subgenus. For example, in all species of $C$. (Hemisiella) in which their biology has been studied, the bees nest in preexisting cavities or trap nest specially made of wood or bamboo cane 
including C. dichrootricha (Moure), C. crassipes Smith, $C$. nitida Smith, C. tarsata Smith, $C$. trigonoides Lepeletier, and C. vittata Lepeletier (Coville et al. 1983; Morato et al. 1999; Aguiar and Garófalo 2004; Vinson et al. 2010).

The potential relationship between $C$. merrillae and its natural enemies (kleptoparasites) can also be inferred from the known information from other related species. For example, nests of C. dichrootricha are attacked by species of the genera Tetraonix sp. (Coleoptera: Meloidae), Coelioxys sp. (Hymenoptera: Megachilidae), and by the species Mesocheira bicolor (Fabricius) (Hymenoptera: Apidae) (Morato et al. 1999); nests of $C$. nitida and $C$. vittata are attacked by Leucospis azteca Cresson, L. bulbiventris Cresson, L. cayennensis Westwood, and L. latifrons Schletterer (Hymenoptera, Leucospidae) (Cooperband et al. 1999); and C. tarsata has also been reported as a host of L. cayennensis (Cooperband et al. 1999), Coelioxys spp., and M. bicolor (Aguiar and Martins 2002). Considering these data, it is probable that the same species could also attack nests of $C$. merrillae, as well as those of other species of the subgenera.

Along with the lack of information on the biology of most solitary bees, which is common for insect species from the megadiverse regions of the world (Whittaker et al. 2005; Bini et al. 2006; Diniz-Filho et al. 2010; Newbold 2010; Cardoso et al. 2011), there is an important deficiency in the knowledge of distribution range of the species that occur in the Neotropical region, including C. merrillae . Consequently, these conditions certainly constitute important obstacles to improving the knowledge on the bionomy, ecology, and geographical distribution of this species that may help in its conservation. Given this context, the objectives of this paper are to increase the knowledge on the biology and geographic distribution of C. merrillae, by describing its nesting biology and nest architecture, increasing its distribution range with new occurrence records, and estimating its potential distribution with different species distribution models (SDMs hereon) that may support future field surveys targeting the discovery of new occurrences of $C$. merrillae.

\section{MATERIAL AND METHODS}

\subsection{Nesting biology}

\subsubsection{Study area}

We studied the nesting biology and nest architecture of Centris merrillae using trap nests disposed in an urban area at the University of the West Indies, Campus St. Augustine, in Trinidad and Tobago (Lat. 10.6418889; Lon. $-61.3995556,22 \mathrm{~m}$ ). Nests were set up in late 2006 and abandoned until early 2008 when bee activity was discovered. The predominant native vegetation in the area is rain forest (Beard 1946), and the mean temperature is approximately $26^{\circ} \mathrm{C}$ with monthly precipitation in the wet season (June-December) of approximately 200$250 \mathrm{~mm}$. (McSweeney et al. 2010).

\subsubsection{Trap nest}

Trap nests were made with bamboo cane of different lengths and cavity diameters (see below). To facilitate analysis and monitoring of the nests, each bamboo was previously cut longitudinally, allowing to easily separate each half. The 22 nests were divided into two groups of 11 and both were hung approximately $8 \mathrm{~m}$ from the ground and separated from each other by about $1 \mathrm{~m}$.

On March 15, 2008, when no activity was recorded for 2 days, we removed the nests from their original location and took them to the laboratory, maintaining similar environmental conditions from that outside (27$32{ }^{\circ} \mathrm{C}$ during the day). To ensure the register of each emergence, we numbered the nests and packaged them into plastic bags with tiny holes to ensure air ventilation.

We examined the nests daily and all emergences were registered. Immediately after we detected bees emerging from their brood cells, we immediately killed, pinned, and labeled the specimens. All voucher specimens are deposited at the Arthropod Collection of the University of the West Indies, Trinidad and Tobago, the entomological collection of the Instituto de Ciencias Naturales de Colombia (ICN), Coleção Entomológica do Museu Nacional, Universidade Federal do Rio de Janeiro, Brazil (MNRJ), and in the Museum für Naturkunde, Humboldt-Universität zu Berlin, Germany (ZMB).

We measured and analyzed nine variables related to C. merrillae's nesting architecture (Table I) with the Shapiro-Wilk W test to know if they were normally 
Table I. Centris merrillae nest variables. Measurements are given in millimeters (mm) except "cell number per nest" and "Internal cell volume"

\begin{tabular}{lccc}
\hline Variable & Number & Range & Mean \pm SD \\
\hline Cavity length & 11 & $123-183$ & $149,07 \pm 15.91$ \\
Nest length & 11 & $51.66-156.49$ & $84.28 \pm 27.13$ \\
Cavity diameter & 11 & $6.59-10.98$ & $9.07 \pm 1.57$ \\
Distance nest plug-trap nest entrance & 11 & $10.10-113.56$ & $50.15 \pm 26.85$ \\
Cell number per nest (no. of cells) & 11 & $3-12$ & $6.71 \pm 2.37$ \\
Internal cell length & 36 & $7.70-11.68$ & $9.47 \pm 0.93$ \\
Internal cell volume $\left(\mathrm{mm}^{3}\right)$ & 36 & $180.18-520.93$ & $314.73 \pm 76.43$ \\
Brood cell partition thick & 33 & $0.92-4.38$ & $2.42 \pm 0.83$ \\
Cell wall thickness & 88 & $0.10-3.94$ & $1.30 \pm 0.68$ \\
\hline
\end{tabular}

Measurements are given in millimeters ( $\mathrm{mm}$ ) except "cell number per nest" and "internal cell volume"

distributed. In addition, we used the Pearson test and both linear and non-linear fit regression models to explore relationships, and likely causalities, between the variables. In addition, for each nest, we evaluated the presence of vestibular cell, number of empty cells, number of dead immatures, parasites emerging, and the number of emerged bees. The terminology of the nest architecture follows Vinson et al. (2010). All measurements are given in millimeters. The expected sex ratio $1: 1$ was analyzed using the Chi-square test of goodness of fit.

\subsection{Occurrence records}

We revised 12 entomological collections looking for occurrence records of Centris merrillae: USDA-ARS Bee Biology and Systematics Laboratory, Logan, USA (BBSL); Claus Rasmussen Bee Collection, Aarhus University, Aarhus, Denmark (CRBC); Colección Entomológica del Instituto Alexander von Humboldt, Villa de Leiva, Colombia (IAvH); Instituto de Ciencias Naturales, Universidad Nacional de Colombia, Bogotá, Colombia (ICN); Laboratorio de Investigaciones en Abejas Silvestres, Universidad Nacional de Colombia, Bogotá, Colombia (LABUN); Museo Argentino de Ciencias Naturales "Bernardino Rivadavia," Buenos Aires, Argentina (MACN); Colección del Museo de Entomología "Francisco Luis Gallego," Universidad Nacional de Colombia, Medellín, Colombia (MEFLG); Museu Nacional, Universidade Federal do Rio de Janeiro, Rio de Janeiro, Brazil (MNRJ); Colección de Entomología Museo Javeriano de
Historia Natural, Bogotá, Colombia (MPUJ); Museo de Entomología de la Universidad del Valle, Cali, Colombia (MUSENUV); Museo Entomológico de la Facultad de Agronomía, Universidad Nacional de Colombia, Bogotá, Colombia (UNAB); and the Smithsonian Institution National Museum of Natural History, Washington, USA (USNM). The type locality was identified by a yellow star in Figure 1 . The information of the examined exemplars is presented in the supplementary material.

\subsection{Potential distribution model}

The new occurrence records found, along with the type locality of Centris merrillae, were used both to model the potential distribution and to establish areas for prioritizing new collections of $C$. merrillae in northern South America and Panama. We georeferenced the localities using the point-radius method (Wieczorek et al. 2004). The methods we used were described elsewhere in previous studies (i.e., Silva et al. 2014a, b, 2015; Martins et al. 2015). Briefly, we applied a principal components analysis to the 19 variables from Worldclim to generate 19 orthogonal principal components (PCs hereon; Table S1, supplementary material), from which we considered the first 4 ( $\sim 90 \%$ of the original climatic variation) to predict the distribution for C. merrillae. In total, we considered five different modeling algorithms, between distance-based and artificial intelligence methods, to predict the species potential distribution. We considered the leave-one-out method (Pearson et al. 2007) to predict the distributions on 


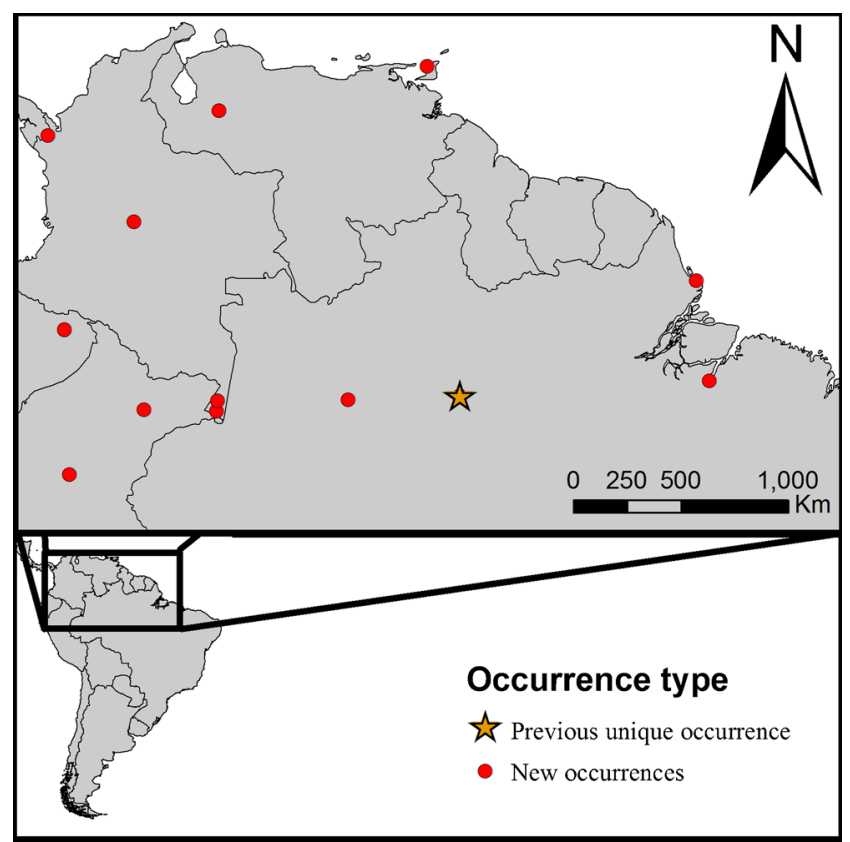

Figure 1. Type locality (yellow star) and occurrence records for Centris merrillae in South America.

C. merrillae with each algorithm and also used the true skill statistics (TSS) metric to evaluate the predicted model accuracy. Detailed information on the modeling procedures we employed are found in the supplementary materials.

\section{RESULTS}

\subsection{Nesting biology}

\subsubsection{Adult emergence, sex ratio, immature mortality, and nest associates}

The 89 cells found in the 14 nests were occupied by $29(32.6 \%)$ males of Centris merrillae, $20(22.5 \%)$ females of C. merrillae, $5(5.6 \%)$ dead preemerged adults, $12(13.5 \%)$ dead larvae, $9(10.1 \%)$ dead pupae, and $9(10.13 \%)$ intercalary empty cells $(\mathrm{SD}=0.84$; range per nest $=1-3$; no. of nest with empty intercalary cells $=6$ ). Additionally, there were three (3.4\%) emergences of males of the kleptoparasitic bee Mesocheira bicolor from three different nests and two (2.2\%) emergences of females of $C$.
(Heterocentris ) analis (Fabricius) within one nest of $C$. merrillae. The sex ratio observed here to C. merrillae was not significantly different from the expected $(1: 1)\left(X^{2}=1.306 ;\right.$ d.f. $=1$; $p=0.253$ ).

The mean difference between the emergences of males and females of $C$. merrillae, measured in days, was $1.6(\mathrm{SD}=1.06$; range $=0-3 ; n=8)$. There were nests that produced (1) only males $(\mathrm{n}=2)$; (2) only females $(n=2)$; (3) both sexes with protandric specimens $(n=5)$; (4) both sexes with protogynous specimens $(n=1)$; (5) specimens of $M$. bicolor and males of $C$. merrillae, where the kleptoparasite emerged first $(n=1)$; (6) specimens of $M$. bicolor and females of C. merrillae, where the kleptoparasite emerged first $(n=1)$; (7) specimens of M. bicolor and both sexes of $C$. merrillae, where the kleptoparasite emerged first $(n=1)$; and (8) specimens of $C$. analis and males of $C$. merrillae, where the former emerged first $(n=1)$. There were two additional nests from which only $C$. analis specimens (four males and five females) emerged. The rest of the bamboo canes $(n=8)$ remained empty. 


\subsubsection{Nest architecture}

The cell walls were made mainly of sand mixed with an oily agglutinating substance. When removed from the nest cavity, the cells have a rough and uneven outer surface (with small bonded sand grains) with the inner surface smooth and covered with an oily substance, which provides a darkbrown coloration. The closure of the cell was made with the same material used in constructing the cells, and it has the appearance of a disk without apparent process on its outer surface but with a slight depression in the center of the inner surface of the cell. As observed in other species of C. (Hemisiella), C. merrillae exhibits a broad range of variation in the number of cells constructed per nest (Table II).

The nest plug was constructed always away from the entrance of the nest cavity (Table I). It is smooth, concave on its external face, and covered with a layer of an oily substance. In the trap nests with small and medium cavity diameters, the plug had a similar appearance to the bottom of a cell, especially those of smaller size. None of the 14 nests of $C$. merrillae had a vestibular cell. The cocoon was brown and translucent, firmly attached to the walls of the cell. Apparently, it consists only in a translucent membrane. The feces were deposited on the basal part of the cells outside the cocoon.

For analyses on nest architecture, 11 of the 14 nests available were used, because the other 3 (from which bees emerged) were in bad condition, making it impossible to obtain measurements from them. The nine variables used on the nest architecture (Table I) had normal distributions. Analyzing the linear correlation between the variables, a high positive correlation was found between cell number per nest and distance from nest plug to the trap nest entrance (Pearson $=0.85007$ ); however, when exploring the relationship between these two variables using both the linear and non-linear fit regression models, no fit within the most used models such as linear, quadratic, exponential, or any polynomial could be found.

The cells were arranged linearly and oriented horizontally. The shape of the cells depended on the cavity diameter and according to it, they can be grouped in three categories: (1) in nests with large cavity diameter, between 10.45 and $10.98 \mathrm{~mm}$ $(n=4)$, the cells were arranged horizontally, approximately in the longitudinal axis of the nest with

Table II. Number of cells per nest in species of Centris (Hemisiella)

\begin{tabular}{lll}
\hline Species & Number & References \\
\hline Centris crassipes & $3-9$ & Jayasingh and Freeman (1980) \\
Centris dichrootricha & $1-7$ & Morato et al. (1999) \\
Centris merrillae & $3-12$ & This work \\
Centris nitida & $1-6$ & Vinson et al. (2010) \\
Centris tarsata & $1-2$ & Mendes and Rêgo (2007) \\
& $6-8$ & Silva et al. (2001) \\
& $2-3$ & Aguiar and Garófalo (2004) \\
Centris transversa & $1-7$ & Aguiar and Garófalo (2004) \\
Centris trigonoides & $2-13$ & Aguiar and Garófalo (2004) \\
& $1-5$ & Batra and Schuster (1977) \\
Centris vittata & $2-8$ & Michener and Lange (1958) \\
& $1-5$ & Aguiar et al. (2006) \\
& $1-8$ & Vinson et al. (2010) \\
\hline
\end{tabular}

\footnotetext{
${ }^{\text {a }}$ Cited as Centris lanipes (Fabricius)
} 
urn form (Figure 2a); (2) in nests with medium cavity diameter, between 9.40 and $9.75 \mathrm{~mm}$ $(n=2)$, the cells were arranged obliquely (Figure 2b); and (3) in nests with small cavity diameter, between 6.59 and $7.37 \mathrm{~mm}(n=4)$, the cells were oriented horizontally, but their shape was more elongated (Figure 2c). One of the nests within a cavity diameter of $9.20 \mathrm{~mm}$ had an intermediate arrangement of the cells between categories 2 and 3 so it was not classified. The bamboo canes that were not used by nesting females had diameters between 6.6 and $11.0 \mathrm{~mm}(n=6$; mean $=8.75 ; \mathrm{SD}=1.92)$.

\subsection{Potential distribution for Centris merrillae}

Considering the LPT threshold, all algorithms but EUC showed TSS values higher than 0.7 (Figure 3), indicative of good distribution prediction. The best prediction was produced by
MAHAL followed by envelope score (ENV), support vector machines (SVMs), genetic algorithm for rule-set prediction (GARP), maximum entropy (MAX), and Euclidean distance (EUC). The sizes of the potential distribution estimated by each algorithm are shown in Table S2 of the supplementary material. While EUC showed the biggest potential range, occupying more than one million grid cells, the predictions produced by the other algorithms produced constrained potential distributions, never superior to 100,000 grid cells. According to the consensus areas for all algorithms, C. merrillae is not present in the Andean mountains. These results may also be observed in the potential distributions for C. merrillae produced by each algorithm (Figure 4). The potential distribution of $C$. merrillae produced with EUC ranged from Central America up to southern Brazil and Paraguay in South America, while the other algorithms showed a more constrained
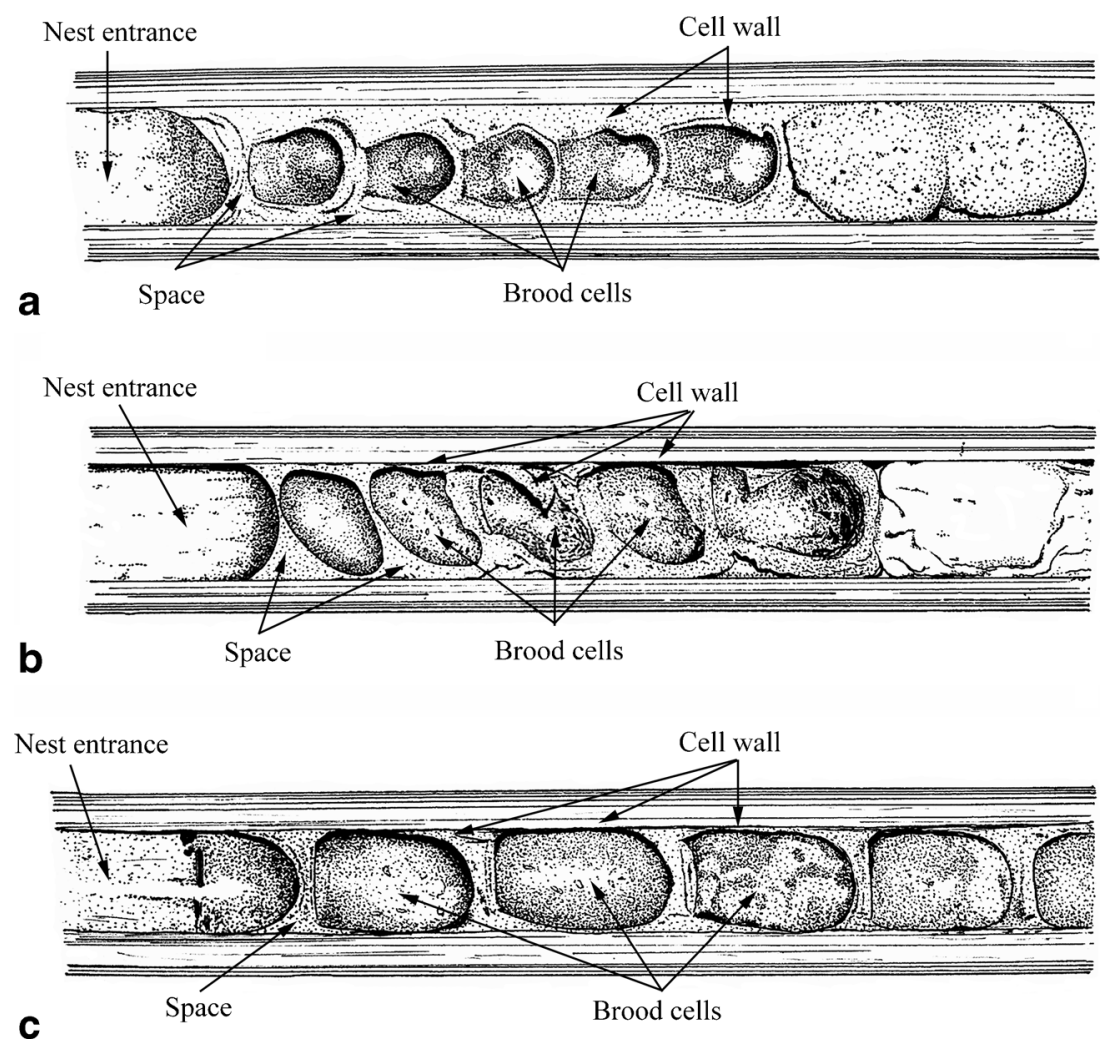

Figure 2. Type of nest of Centris merrillae. a Cells horizontally arranged, with urn form. b Cells obliquely arranged. c Cells horizontally arranged, elongated shape. The term "space" refers to the space between the cells and cavity wall that is filled with sand or wood chips (Vinson et al. 2010), sand in the case of C. merrillae. 


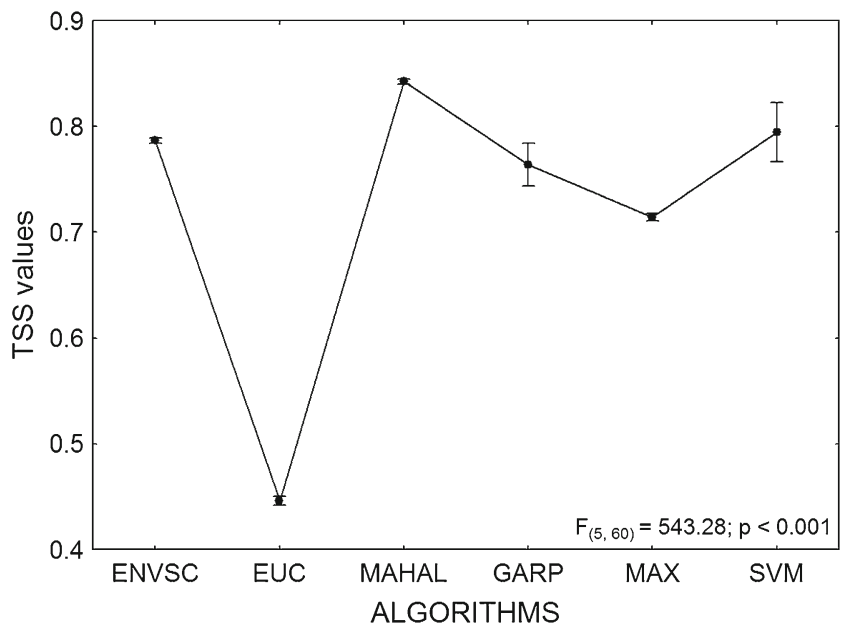

Figure 3. Distribution models statistics. Values for the true skill statistics (TSS) obtained for the potential distributions modeled with each different algorithm, under the LPT threshold for Centris merrillae in South America. Mahalanobis Distance (MAHAL), envelope score (ENV), support vector machines (SVMs), genetic algorithm for rule-set prediction (GARP), maximum entropy (MAX), and Euclidean distance (EUC).

potential range for $C$. merrillae, within the Amazon. It is noteworthy that GARP and SVM, in some occurrence subsets, also predicted some suitable grid cells for this species in southern South America that certainly are not occupied by the species. Nonetheless, some areas in northern

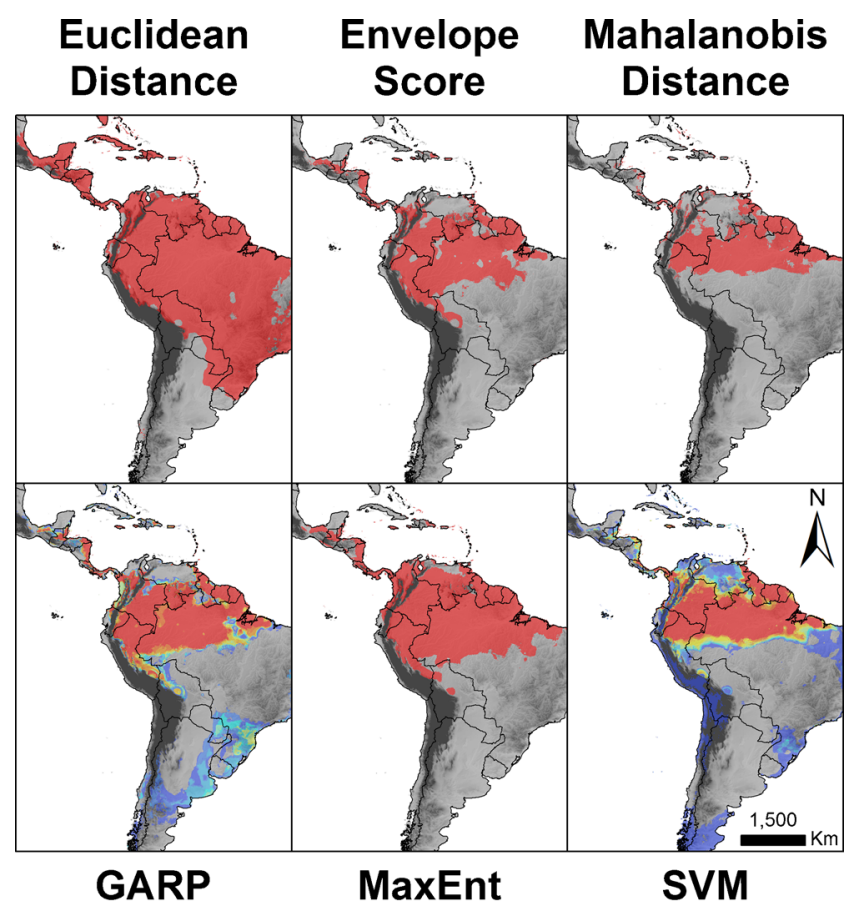

Figure 4. Current potential distributions for Centris merrillae in South America, considering both distance (above maps ) and artificial intelligence (below maps) modeling algorithms. 
Venezuela and northeastern Colombia were predicted to be suitable for some occurrence subsets, according to the SVM algorithm.

Considering the summed distribution predicted by all the six algorithms used (Figure 5a), the potential range of C. merrillae is taking into account areas predicted to have the presence of at least two algorithms because they included all the occurrence records used in this analysis and did not show overprediction of the grid cells. Areas of $350 \mathrm{~km}$ away from the known occurrences of $C$. merrillae should be considered as suitable areas for the species occurrence in future field surveys, as well as areas for the evaluation of the produced potential distributions.

The final ensemble corresponding to the potential distribution for C. merrillae (Figure 5b) showed a high superposition with most of the biogeographic provinces proposed by Morrone (2014) for the Pacific, Boreal, and South Brazilian dominions (Brazilian subregion). The species is present in almost all the Amazonas, except for some southern areas such as the southern part of the Rondônia province. The same happened within most of the territory of the Venezuelan province in the Pacific dominion. Other provinces of this latter region such as the Puntarenas-Chiriquí, Guatuso-Talamanca, Chocó-

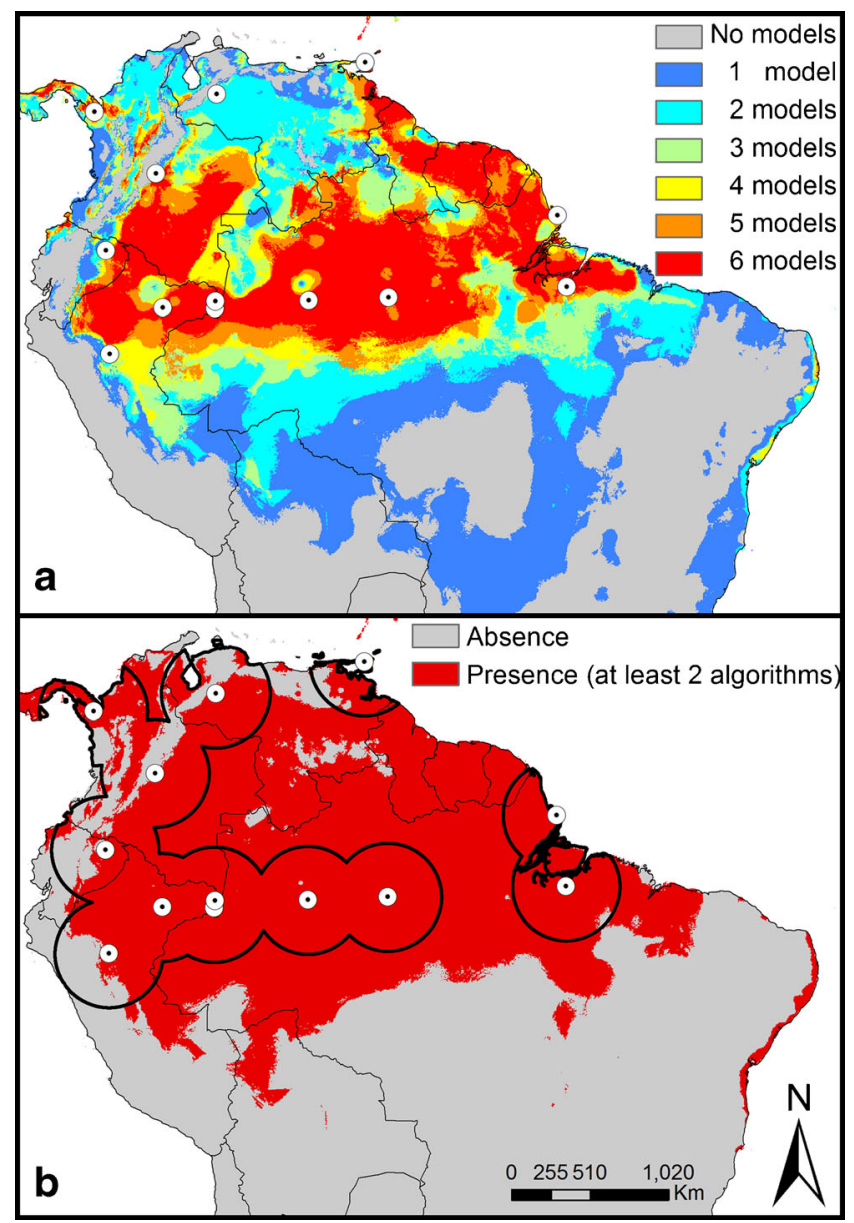

Figure 5. Summed (a) and mean ensemble distribution (b) for Centris merrillae in South America. The ensemble distribution depicted in $\mathbf{b}$ considered areas predicted by at least two different algorithms as suitable for the modeled species. 
Darién, Magdalena, Cauca, Western Ecuador, and Trinidad fitted very well with the proposed potential distribution for C. merrillae .

\section{DISCUSSION}

\subsection{Nesting biology}

There are many patterns concerning both the nesting biology and the architecture of solitary bees and wasps nesting in preexisting holes in wood or trap nests made of wood or bamboo canes (Krombein 1967). Here, we discuss some of them considering the information available for other species of Centris (Hemisiella) and for C. merrillae according to the results obtained here.

\subsubsection{Sand and agglutinating substance as material used to construct the nest}

As described in this work for C. merrillae, several species of $C$. (Hemisiella) that have been found nesting in horizontal trap nests made of wood or bamboo canes, such as C. dichrootricha (Morato et al. 1999), C. nitida, C. trigonoides (Vinson et al. 2010), C. tarsata (Silva et al. 2001; Aguiar and Garófalo 2004; Mendes and Rêgo 2007), and C. vittata (Pereira et al. 1999; Vinson et al. 2010), construct their nests using a mixture of sand and an agglutinating substance. On the other hand, in natural or seminatural conditions, $C$. trigonoides (cited as C. lanipes ) used sandy clay to construct their nest in both preexisting holes in old pieces of logs and in wooden buildings (Michener and Lange 1958). The material described by these authors as sandy clay is probably also sand mixed with an agglutinating substance. In natural conditions, C. transversa was found nesting in a bank made of fine layers of loess-like soil and volcanic ash, and the cells were constructed with a mixture of mud and a waxy or resinous substance (Batra and Schuster 1977). This material can also be understood as a mixture of sand and an agglutinating substance as observed with other species of the subgenus. The use of sand by females of $C$. (Hemisiella) to construct their nest appears to be a characteristic behavioral pattern that differentiates the group from its closest relative subgenus $C$. (Heterocentris) Cockerell, in which the species use sawdust and other vegetal resources as materials for the construction of their nests (Coville et al. 1983; Aguiar and Garófalo 2004; Vinson et al. 2010).

\subsubsection{Cell arrangement, shape, and number of cells per nest}

Jesus and Garófalo (2000) pointed out that in species of the subgenera $C$. (Heterocentris), $C$. (Hemisiella), and C. (Xanthemisia) Moure, the number and arrangement of cells varied with the size of the cavity utilized. In some species of $C$. (Hemisiella), such as C. nitida and C. trigonoides, the shape of the cells and their horizontal orientation can vary depending on the cavity diameter.

In general, the females of these two species tend to construct tubular cells in linear sequence, orienting them horizontally in nests with relatively small diameters $(8.0 \mathrm{~mm}$ or less). In nests with relatively large cavity diameters $(11.0 \mathrm{~mm}$ or more), these species construct cells with variable and irregular shapes oriented slightly more vertically than in narrower nests (Vinson et al. 2010).

Variation in the number of cells per nest is a common feature in species of $C$. (Hemisiella), including within the same species in similar conditions. The number of cells constructed by females of $C$. merrillae also had a broad variation between 3 and 12. The length of the cavity does not appear to be the factor that determines the number of cells constructed. As shown in this paper, the nest plug was always constructed away from the entrance of the nest cavity, leaving enough space to construct more cells in the majority of the nests, as described for C. tarsata (Silva et al. 2001).

Species of other subgenera of Centris also showed plasticity in the number of cells built per nest, even within the same population. Martins et al. (2013) studied the nesting behavior of the ground-nesting bee $C$. (Centris) flavifrons (Fabricius) and suggested that it is reproductively advantageous for females to build many cells per nest instead of just one because of the optimization of energy to construct the nest. The same 
authors, in the same work, pointed out that the possible number of cells built per nest can be diminished because of the other perturbations by other nesting females or parasites that may cause the nesting female to close the nest and start another one.

\subsubsection{Nest plug covered with a layer of an oily substance}

The information available about trap nesting bees show that females of several species of $C$. (Hemisiella) cover the outer surface of the nest plug with an oily substance. This fact has been observed in C. nitida (Vinson et al. 2010), C. trigonoides (Aguiar et al. 2006, Vinson et al. 2010), C. tarsata (Aguiar and Garófalo 2004), C. vittata (Pereira et al. 1999; Ramos et al. 2010; Vinson et al. 2010), and now for C. merrillae. This character has also been described for C. analis (Jesus and Garófalo 2000) and C. bicornuta Mocsáry (Frankie et al. 1988), two species belonging to the subgenus $C$. (Heterocentris). The covering of the nest plug with an oily substance makes the plug harder, and, in consequence, the access of the natural enemies into the nests becomes more difficult (Pereira et al. 1999; Jesus and Garófalo 2000; Gazola and Garófalo 2003).

\subsubsection{Vestibular and empty cells}

Vestibular and empty cells in the nests of bees and wasps are usually associated with a mechanism for reducing the attack of kleptoparasites (e.g. Pérez Maluf 1993, apud Mendes and Rêgo 2007). Vestibular cells in the nests of species of $C$. (Hemisiella) have been described for C. vittata, C. nitida, C. trigonoides (Vinson et al. 2010), and C. tarsata (Silva et al. 2001). In this latter species, vestibular cells were found in $19 \%$ of the nests studied. The absence of vestibular cells was reported for C. dichrootricha (Morato et al. 1999) and now in $C$. merrillae. On the other hand, intercalary empty cells were found in the nests of this species, as described for C. tarsata (Silva et al. 2001; Mendes and Rêgo 2007).

\subsubsection{Adult emergence, sex ratio, immature mortality, and nest associates}

In solitary bees, it has been suggested that immature mortality, except when due to kleptoparasites, can be associated with climatic factors, such as high temperatures (Frankie et al. 1988; Jesus and Garófalo 2000; Aguiar and Garófalo 2004). In species of $C$. (Hemisiella), immature mortality attributed to unknown causes has been described in $C$. vittata with rates of 26.1 and $15.9 \%$ in two localities at Cajuru (Sao Paulo state, Brazil) (Pereira et al. 1999), in C. tarsata with 41.3 and $42.1 \%$ in Baixa Grande and Ipirá (Bahia state, Brazil), respectively (Aguiar and Garófalo 2004), and now in C. merrillae with $29.2 \%$ of immature mortality.

The development of solitary wasps and bees that use trap nests is shorter in males than in females. Usually, the cells where males grow are built closer to the nest's entrance, while the females' cells are built in the lower part of the nest. Apparently, this facilitates the adult emergence in protandric species, like $C$. dichrootricha (Morato et al. 1999), C. tarsata (Silva et al. 2001), C. vittata (Pereira et al. 1999; Ramos et al. 2010), and C. merrillae. However, in one of the nests studied here of this latter species, the females emerged first, being an exception to the apparently widely observed pattern in the species of the subgenus.

The record of $M$. bicolor attacking nests of C. merrillae increases the number of hosts reported for this kleptoparasitic bee; all host records available show that this parasite attacks exclusively nests of species of $C$. (Hemisiella) and $C$. (Heterocentris ) (Rocha-Filho et al. 2009).

Despite being a well-known pollen-collecting bee, $C$. analis has been recorded performing intraspecific kleptoparasitism (Jesus and Garófalo 2000). In this study, specimens of both C. analis and $C$. merrillae emerged from a single nest. This could mean that under specific circumstances, C. analis performs intraspecific and/or interspecific kleptoparasitism, in this case using C. merrillae as host. As observed by Jesus and Garófalo (2000), this behavior could not be related with the lack of empty trap nests, because there were bamboo canes available for $C$. analis 
nesting. Although, this behavior could be a strategy to reduce time and energy investment in constructing their own nest as suggested for other Centris species such as C. flavifrons (Martins et al. 2013).

\subsection{Potential and known distribution}

With this work, the known distribution range of C. merrillae has been extended to Ecuador, Peru, Venezuela, and Trinidad and Tobago. The production of the distribution range assessment has shown that this species has a potential distribution that includes almost all of the provinces of the Brazilian subregion (sensu Morrone 2014), except for the Mesoamerican dominion. This potential distribution pattern could be expected in several species of $C$. (Hemisiella), as well as in other species of the genus that occur in northern South America. It has been suggested that the highest richness of this subgenus occurs in South America (Snelling 1984; Silveira et al. 2002), especially in tropical areas of the north of the subcontinent, where 9 of the 17 known species occur (Moure et al. 2007). Nevertheless, the few occurrence records available for $C$. merrillae could hinder the proper assessment of their distribution ranges and, consequently, field survey optimization and the implementation of practical conservation actions (Whittaker et al. 2005; Bini et al. 2006; Silva et al. 2013). Nonetheless, given the complete lack of distribution estimates, any available potential distribution is useful to propose new areas where field surveys need to be deployed to gain newer information on this species. In this sense, SDMs are being constantly used elsewhere to shed some light on the potential distribution of different species groups, including South American bees (e.g., Raxworthy et al. 2003; Almeida et al. 2010; Silva et al. 2013). Therefore, the different South American areas highlighted in Figure 5 are indicated as suitable for new entomological surveys for the sampling of new occurrences for C. merrillae. Future surveys should be performed in South and Central America in countries such as Belize, Costa Rica, Guatemala, Honduras, Nicaragua, and Panama, countries with suitable areas and that are relatively near the currently known occurrences for $C$. merrillae.

\section{ACKNOWLEDGMENTS}

We want to thank Christopher Starr for allowing the use of his trap nests; Carlos Alberto Garófalo for the comments about the nest architecture; and Juanita Rodríguez (BBSL), Claus Rasmussen (CRBC), Claudia Medina (IAvH), José Ricardo Cure (UMNG), Fernando Fernández (ICN), Rodulfo Ospina (LABUN), Arturo Roig-Alsina (MACN), Jhon Quiroz (MEFLG), Dimitri Forero (MPUJ), Carmen Posso (MUSENUV), Francisco Serna (UNAB), Brian Harris, and David Furth (USNM) for the loaned specimens and pictures. We also thank Rubén Albarracín for helping in georeferencing the localities and to the anonymous reviewers for the comments and suggestions that helped to improve this article. Financial support was partially provided to FV by Fundação Carlos Chagas Filho de Amparo à Pesquisa do Rio de Janeiro, Brazil (FAPERJ, grant E-26/110.416/2014) and Conselho Nacional de Desenvolvimento Científico e Tecnológico (CNPq, grant 444320/2014-8), Brazil. This paper is part of the SIGMA project $\mathrm{N}^{\circ} 21565 \mathrm{MN} / \mathrm{UFRJ}$ and the contribution number 15 from the HYMN.

Biologie de la nidification et distribution potentielle d'une abeille récolteuse d'huile (Centridini) d'Amérique du Sud

Centridini / Centris merrillae / aire de répartition / région néotropicale / abeille solitaire

Nistbiologie und potentielle Verbreitung ölsammelnder Centridine Bienen Südamerikas

Centridini / Centris merrillae / Verbreitungsgrad / neotropische Region / solitäre Biene

\section{REFERENCES}

Aguiar, M.L., Garófalo, C.A. (2004) Nesting biology of Centris (Hemisiella) tarsata Smith (Hymenoptera, Apidae, Centridini). Rev. Bras. Zool. 21, 477-486.

Aguiar, A.J.C., Martins, C.F. (2002) Abelhas e vespas solitárias em ninhos-armadilha na Reserva Biológica Guaribas (Mamanguape, Paraíba, Brasil). Rev. Bras. Zool. 19, 101-116.

Aguiar, C.M.L., Garófalo, C.A., Almeida, G.F. (2006) Biologia de nidificação de Centris (Hemisiella) trigonoides Lepeletier (Hymenoptera, Apidae, Centridini). Rev. Bras. Zool. 23, 323-330. 
Almeida, M.C., Côrtes, L.G., De Marco, Jr P. (2010) New records and a niche model for the distribution of two Neotropical damselflies: Schistolobos boliviensis and Tuberculobasis inversa (Odonata: Coenagrionidae). Insect Conserv. Divers. 3, 252-256.

Batra, S.W., Shuster, L.C. (1977) Nests of Centris, Melissodes and Colletes in Guatemala (Hymenoptera: Apoidea). Biotropica 9, 135-138.

Beard, J.S. (1946) The Natural Vegetation of Trinidad. Oxford: Clarendon $152 \mathrm{pp}$.

Bini, L.M., Diniz-Filho, J.A.F., Rangel, T.F., Bastos, R.P., Pinto, M.P. (2006) Challenging Wallacean and Linnean shortfalls: Knowledge gradients and conservation planning in a biodiversity hotspot. Divers. Distrib. 12, 475-482.

Cardoso, P., Erwin, T.L., Borges, P.A.V., New, T.R. (2011) The seven impediments in invertebrate conservation and how to overcome them. Biol. Conserv. 144, 26472655.

Cooperband, M.F., Frankie, G.W., Wharton, R.A., Vinson, S.B. (1999) New host and distribution records for Leucospis (Hymenoptera: Leucospidae) associated primarily with nests of Centris (Hymenoptera: Anthophoridae) in the forest of Costa Rica. J. Hymenopt. Res. 8, 154-164.

Coville, R., Frankie, G.,Vinson, S.B. (1983) Nests of Centris segregata (Hymenoptera, Anthophoridae) with a review of the nesting habits of the genus. J. Kansas Entomol. Soc. 56, 109-122.

Diniz-Filho, J.A.F., De Marco P Jr., Hawkins, B.A. (2010) Defying the curse of ignorance: perspectives in insect macroecology and conservation biogeography. Insect. Conserv. Diver. 3, 172-179.

Frankie, G.W., Vinson, S.B., Newstrom, L.E., Barthell, J.F. (1988) Nest site and habitat preferences of Centris bees in the Costa Rican dry forest. Biotropica 20, 301-310.

Gaglianone, M.C., Aguiar, A.J.C., Vivallo, F., Alves-dosSantos, I. (2011) Checklist das abelhas coletoras de óleos do Estado de São Paulo. Biota Neotrop. 11, 657666.

Gazola, A., Garófalo, C. A. (2003) Parasitic Behavior of Leucospis cayennensis Westwood (Hymenoptera: Leucospidae) and rates of parasitism in populations of Centris (Heterocentris ) analis (Fabricius) (Hymenoptera: Apidae: Centridini). J. Kansas Entomol. Soc. 76,131-142.

Jayasingh, D.B., Freeman, B.E. (1980) Trap-nesting solitary aculeates (Insecta: Hymenoptera) in St. Catherine Jamaica. Caribb. J. Sci. 15, 69-78.

Jesus, B.M.V., Garófalo, C.A. (2000) Nesting behavior of Centris (Heterocentris) analis (Fabricius) in southeastern Brazil (Apidae, Centridini). Apidologie 31, 503-515.

Krombein, K.V. (1967) Trap-nesting wasps and bees. Life histories, nests and associates, Smithsonian Press, Washington.

Martins, A.C., Silva, D.P., De Marco, Jr P., Melo, G.A.R. (2015) Species conservation under future climate change: the case of Bombus bellicosus, a potentially threatened South American bumblebee species. J. Insect Conserv. 19, 33-43.

Martins, C. F., Peixoto, M., Aguiar, C. (2013) Plastic nesting behavior of Centris (Centris) flavifrons (Hymenoptera: Apidae: Centridini) in an urban area. Apidologie 45, 156-171.

McSweeney, C., New, M., Lizcano, G. (2010) UNDP Climate Change Country Profiles: Trinidad and Tobago [online] http://country-profiles.geog.ox.ac.uk/ (Accessed on 18 October 14).

Mello, M., Bezerra, E., Machado, I. (2013) Functional roles of Centridini oil bees and Malpighiaceae oil flowers in biome-wide pollination networks. Biotropica 45, 45-53.

Mendes, F.N., Rêgo, M.M.C. (2007) Nidificação de Centris (Hemisiella) tarsata smith (hymenoptera, Apidae, Centridini) em ninhos-armadilha no Nordeste do Maranhão, Brasil. Rev. Bras. Entomol. 51, 382-288.

Michener, C.D. (2007) The Bees of the World. Johns Hopkins University Press, Baltimore, Maryland, 2nd Edition, 992 pp.

Michener C.D., Lange R.B. (1958) Observations on the ethology of Neotropical anthophorine bees (Hymenoptera: Apoidea), Univ. Kans. Sci. Bull. 39, 69-96.

Morato, E., Garcia, M.V.B., Campos, L.A.O. (1999) Biologia de Centris Fabricius (Hymenoptera, Anthophoridae, Centridini) em matas contínuas e fragmentos na Amazônia Central. Rev. Bras. Zool. 16, 1213-1222.

Moure, J.S., Melo, G.A.R., Vivallo, F. (2007) Centridini Cockerell and Cockerell. In: Moure, J.S., Urban, D., Melo, G.A.R. (Orgs), Catalogue of Bees (Hymenoptera, Apoidea) in the Neotropical Region. Sociedade Brasileira de Entomologia, Curitiba, Brazil, pp. 83142.

Morrone, J.J. (2014) Biogeographical regionalisation of the Neotropical región. Zootaxa 3782, 1-100.

Newbold, T. (2010) Applications and limitations of museum data for conservation and ecology, with particular attention to species distribution models. Prog. Phys. Geogr. 34, 3-22.

Pearson, R.G., Raxworthy, C.J., Nakamura, M., Peterson A.T. (2007) Predicting species distributions from small numbers of occurrence records: a test case using cryptic geckos in Madagascar. J. Biogeogr. 34, 102-117.

Pereira, M., Garófalo, C.A., Camillo, E., Serrano, J.C. (1999) Nesting biology of Centris (Hemisiella) vittata Lepeletier in southeastern Brazil (Hymenoptera,Apidae, Centridini). Apidologie 30, 327-338.

Perez-Maluf, R. (1993) Biologia de vespas e abelhas solitárias, em ninhos-armadilhas, em Viçosa - MG. Universidade Federal de Viçosa. Dissertação de Mestrado. 87 p.

Ramos, M., Albuquerque, P., Rêgo, M. (2010) Nesting Behavior of Centris (Hemisiella) vittata Lepeletier (Hymenoptera: Apidae) in an Area of the Cerrado in the Northeast of the State of Maranhão, Brazil. Neotrop. Entomol. 39, 379-383. 
Rasmussen, C., Vivallo, F. (2014) Lectotype designations and new synonymies in the Neotropical bee genus Centris Fabricius, 1804 (Hymenoptera: Apidae). Zootaxa 3856, 585-594.

Raxworthy, C.J., Martínez-Meyer, E., Horning, N., Nussbaum, R.A., Schneider, G.E., Ortega-Huerta, M.A., Peterson, A.T, (2003) Predicting distributions of known and unknown reptile species in Madagascar. Nature 426, 837-841.

Rocha-Filho, L.C., Morato, E.F., Melo, G.A.R. (2009) New host records of Aglaomelissa duckei and a compilation of host associations of Ericrocidini bees (Hymenoptera: Apidae). Zoologia 26, 299-304.

Silva, F.O., Viana, B.F., Neves, E.L. (2001) Biologia e arquitetura de ninhos de Centris (Hemisiella) tarsata Smith (Hymenoptera: Apidae: Centridini). Neotrop. Entomol. 30, 541-545.

Silva, D.P., Aguiar, A.J.C., Melo, G.A.R., Anjos-Silva, E.J., de Marco Jr., P. (2013) Amazonian species within the Cerrado savanna: new records and potential distribution for Aglae caerulea (Apidae: Euglossini). Apidologie 44, 383-673.

Silva D.P., Gonzalez, V.H., Melo, G.A.R., Lucia, M., Alvarez, L.J., De Marco, Jr P. (2014a) Seeking the flowers for the bees: integrating biotic interactions into niche models to assess the distribution of the exotic bee species Lithurgus huberi in South America. Ecol. Model. 273, 200-209.
Silva D.P., Macêdo, A.C.B.A., Ascher, J.S., De Marco, Jr P. (2015) Range increase of a Neotropical orchid bee under future scenarios of climate change. J. Insect Conserv. 19, 901-910.

Silva, D.P., Vilela, B., Marco, P. de., Nemésio, A. (2014b) Using ecological niche models and niche analyses to understand speciation patterns: the case of sister Neotropical orchid bees. PLoS One 9, e113246.

Silveira, F.A., Melo, G.A.R., Almeida, E.A.B. (2002) Abelhas brasileiras Sistemática e Identificação. Fundação Araucária, Belo Horizonte, 254 pp.

Snelling, R.R. (1984) Studies on the taxonomy and distribution of American Centridine bees (Hymenoptera: Anthophoridae). Contr. Sci. Mus. Nat. His. Los Angeles. 347, 1-69.

Vinson, S.B., Frankie, G., Cônsoli, R. (2010) Description, comparison and identification of nests of cavitynesting Centris bees (Hymenoptera: Apidae: Centridini) in Guanacaste Province, Costa Rica. J. Kansas Entomol. Soc. 83, 25-46.

Wieczorek, J., Guo, Q., Hijmans, R.J. (2004) The pointradius method for georeferencing locality descriptions and calculating associated uncertainty. Int. J. Geogr. Inf. Sci. 18, 745-767.

Whittaker, R.J., Araújo, M.B., Jepson, P., Ladle, R.J., Watson, J.E.M., Willis, K.J. (2005) Conservation biogeography: Assessment and prospect. Divers. Distrib. 11, $3-23$. 